DIVISION OF THE HUMANITIES AND SOCIAL SCIENCES

CALIFORNIA INSTITUTE OF TECHNOLOGY

PASADENA, CALIFORNIA 91125

PROSPECT THEORY IN THE WILD: EVIDENCE FROM THE FIELD

Colin F. Camerer

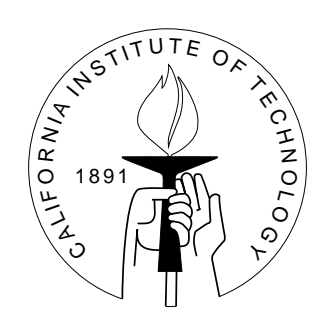

SOCIAL SCIENCE WORKING PAPER 1037

May 1998 


\title{
Prospect theory in the wild: Evidence from the field
}

\author{
Colin Camerer*
}

The workhorses of economic analys is are simple formal models which can explain naturally-occurring phenomena. Reflecting this taste, economists often say they will incorporate more psychologicalideas into economics if those ideas can parsimoniously account for field data better than standard theories do. Taking this statement seriously, this paper describes ten regularities in naturally-occurring data which are anomalies for expected utility theory, but can all be explained by three simple elements of prospect theory-- loss-aversion, reflection effects, and nonlinear weighting of probability-- along with the assumption that people isolate decisions (or edit them) from others they might be gro uped with (Read, Loewenstein, and Rabin, 1998; cf. Thaler, this volume). I hope to show how much success has already been had applying prospect theory to field data, and to inspire economists and psychologists to spend more time in the wild.

The 10 patterns are summarized in Table 1. To keep the paper brief, I sketch expected utility and prospect theory very quickly. (Readers who want to know more should look elsewhere in this volume or in Camerer, 1995, or Rabin, 1998a). In expected utility, gambles which yield risky outcomes $x_{i}$ with probabilities $p_{i}$ are valued according to $p_{i} u\left(x_{i}\right)$ where $u(x)$ is the utility of outcome $x$. In prospect the ory they are valued by $\left(p_{i}\right) v\left(x_{i}-r\right)$, where $(p)$ is a function which weights probabilities nonlinearly, o verweight ing probabilities below . 3 or so and underweighting larger probabilities. ${ }^{1}$ The value function $\mathrm{v}(\mathrm{x}-\mathrm{r})$ exhibits diminishing marginal sensitivity to deviations from the reference point $r$, creating a reflection effect because $v(x-r)$ is convex for losses and concave for gains (i.e., $\mathrm{v}(\mathrm{x}-\mathrm{r})>0$ for $\mathrm{x}<\mathrm{r}$ and $\mathrm{v}(\mathrm{x}-\mathrm{r})<0$ for $\mathrm{x}>\mathrm{r}$ ). The value function also exhibits loss-aversion -- the value of a loss - $x$ is larger in magnitude than the value of an equal-sized gain (i.e., $-\mathrm{v}(-\mathrm{x})>\mathrm{v}(\mathrm{x})$ for $\mathrm{x}>0)$.

\section{Finance: The equity premium}

Two important anomalies in finance can be explained by elements of prospect theory.

* This paper was prepared for D. Kahneman and A. Tversky (Eds.), Choices, Values and Frames (in press). The research was supported by NSF grant SBR-9601236 and the hospitality of the Center for Advanced Study in Behavioral Sciences during 1997-98. Linda Babcock and Barbara Mellers gave helpful suggestions.

${ }^{1}$ In rank-dependent approaches, the weights at tached to outcomes are differences in weighted cumulative probabilities. For example, if the outcomes are ordered $x_{1}>x_{2}>\ldots>x_{n}$, the weight on outcome $x_{i}$ is $\left(p_{1}+p_{2}+. . p_{i}\right)-\left(p_{1}+p_{2}+\ldots p_{i-1}\right)$. (Notice that if $(p)=p$ this weight is just the probability $\mathrm{p}_{\mathrm{i}}$.). In cumulative prospect theory gains and losses are ranked and weighted separately (by magnitude). 
One anomaly is called the equity premium . Stocks-- or equities -- tend to have more variable annual price changes (or returns ) than bonds do. As a result, the average return to stocks is higher, as a way of compensating investors for the additional risk they bear. In most of this century, for example, stock returns were about $8 \%$ per year higher than bond returns. This was accepted as a reasonable return premium for equities until Mehra and Prescott (1985) asked how large a degree of risk-aversion is implied by this premium. The answer is surprising-under the standard assumptions of economic theory, investors must be extremely risk-averse to demand such a high premium. For example, a per son with enough risk-aversion to explain the equity premium would be indifferent between a coin flip paying either $\$ 50,000$ or $\$ 100,000$, and a sure amount of $\$ 51,329$.

Explaining why the equity premium is so high has preocc upied financial economists for the last fifteen years (see Siegel and Thaler, 1997). Benartzi and Thaler (1997) suggested a plausible answer based on prospect theory. In their theory, investors are not averse to the variability of returns, they are averse to loss (the chance that returns are negative). Since annual stock returns are negative much more frequently than annual bond returns are, lo ss-averse investors will demand a large equity premium to compensate them for the much higher chance of losing money in a year. Keep in mind that the higher average return to stocks means that the cumulative return to stocks over a longer horizon is increasingly likely to be positive as the horizon lengthens. Therefore, to explain the equity premium Benartzi and Thaler must assume that investors take a short horizon, over which stocks are more likely to lose money than bonds. They compute the expected prospect values of stock and bond returns over various horizons, using estimates of investor utility functions from Kahneman and Tversky (1992), and including a loss-aversion coefficient of 2.25 (i.e., the disutility of a small loss is 2.25 times as large as the utility of an equal gain). Benartzi and Thaler show that over a one-year horizon, the prospect values of stock and bond returns are about the same if stocks return $8 \%$ more than bonds, which explains the equity premium.

\section{Finance: The disposition effect}

Shefrin and Statman (1985) predicted that because people dislike incurring losses much more than they like incurring gains, and are willing to gamble in the domain of losses, investors will hold on to stocks that have lost value (relative to the ir purchase price) to o long and will be eager to sell stocks that have risen in value. They called this the disposition effect. The disposition effect is anomalous because the purchase price of a stock should not matter much for whether you decided to sell it. If you think the stock will rise, you should keep it; if you think it will fall, you should sell it. In addition, tax laws encourage people to sell losers rather than winners, since such sales generate losses which can be used to reduce the taxes owed on capital gains.

Disposition effects have been found in experiments by (Weber and Camerer, 1998) ${ }^{2}$. On

${ }^{2}$ In the Weber and Camerer experiment, subjects who se shares were automat ically sold every period (but could be bought back with no transaction cost) did not buy back the shares of 
large exchanges, trading volume of stocks that have fallen in price is lower than for stocks that have risen. The best field study was do ne by Odean (in press). He obtained data from a brokerage firm about all the purchases and sales of a large sample of individual investors. He found that investors held losing stocks a median of 124 days, and held winners only 104 days. Investors sometimes say they hold losers because they expect them to bounce back (or meanrevert) but in Odean s sample, the un sold losers returned only $5 \%$ in the subsequent year, while the winners that were sold later returned $11.6 \%$. Interestingly, the winner-loser differences did disappear in December. In this month investors have their last chance to incur a tax advantage from selling losers (and selling winners generates a taxable capital gain) so their reluctance to incur losses is temporarily overwhelmed by their last chance to save on taxes.

\section{Labor supply}

Camerer, Babcock, Loewenstein and Thaler (this volume) talked to cab drivers in New York City about when they decide to quit driving each day. Most of the drivers lease their cabs, for a fixed fee, for up to 12 hours. Many said they set an income target for the day, and quit when they reach that target. While daily income targeting seems sensible, it implies that drivers will work long hours on bad days when the per-hour wage is low, and will quit earlier on good high-wage days. The standard theory of the supply of labor predicts the opposite: Drivers will work the hours which are most profitable, quitting early on bad day, and making up the shortfall by working longer on good days.

The daily targeting theory and the standard theory of labor supply therefore predict oppo site signs of the correlation between hours and the daily wage. To meas ure the correlation, we collected three samples of data on how many hours drivers w orked on different days. The correlation between hours and wages was strongly negative for inexperienced drivers and close to zero for experienced drivers. This suggests that inexperienced drivers beg an us ing a daily inco me targeting heuristic, but those who did so either tended to quit, or learned by experience to shift to ward driving aro und the same number of hours every day.

Daily income targeting assumes los s-aversion in an indirect way. To explain why the correlation between hours and wages for inexperienced drivers is so strongly negative, one needs to assume that drivers take a one-day horizon, and have a utility funct ion for the day s income which bends sharply at the daily income target. This bend is an aversion to losing by falling short of an income reference point.

\section{Asymmetric price elasticities of consumer goods}

The price elasticity of a good is the change in quantity demanded, in percentage terms,

losers more than winners. This show s they are not optimistic about the losers, but simply reluctant to sell them and lock in a realized loss. 
divided by the percentage change in its price. Hundreds of studies estimate elasticities by looking at how much purchases change after prices change. Loss-averse consumers dislike price increases more than they like the windfall gain from price cuts, and will cut back purchases more when prices rise, compared to the extra amount they buy when prices fall. Loss-aversion therefore implies elasticities will be asymmetric-- elasticities will be larger in magnitude after price increases than after price decreases. Putler (1992) looked for such an asymmetry in price elasticities in consumer purchases of eggs, and found it.

Hardie, Johnson, and Fader (1993) replicated the study using a typical model of brand choice in which a consumer s utility for a brand is unobserved, but can be estimated by observing purchases. They included the possibility that consumers compare a good s current price to a reference price (the last price they paid) and get more disutility from buying when prices have risen than the extra utility they get when prices have fallen. For orange juice, they estimate a coefficient of loss-aversion around 2.4.

Note that for loss-aversion to explain these results, consumers must be narrowly bracketing purchases of a specific good (eggs, or orange juice). Otherwise, the loss from paying more for one good would be integrated with gains or losses from other goods in their shopping cart, and would not loom so large.

\section{Savings and consumption: Insensitivity to bad news}

In economic models of lifetime savings and consumption decisions, people are assumed to have separate utilities for consumption in each period, denoted $\mathrm{u}(\mathrm{c}(\mathrm{t}))$, and discount factors which weight future consumption less than current consumption. These models are used to predict how much rational consumers will consume (or spend) now and how much they will save, depending on their current income, anticipations of future income, and their discount factors. The models make many predictions which seem to be false. The central prediction is that people should plan ahead by anticipating fut ure income to make a guess about their permanent income, and consume a const ant fraction of that total in any one year. Since most workers earn larger and larger incomes throughout their lives, this prediction implies that people will spend more than they earn when they are young-- borrowing if they can-- and will earn more than they spend when they are older. But in fact, spending on consumption tends to be close to a fixed fraction of current income, and does not vary across the life cycle nearly as much as standard theory predicts. Consumption also drops steeply after retirement, which it should not if people anticipate retirement and save enough for it.

Shea (1995) point ed out a nother prediction of the standard life-cycle theory. Think of a group of workers whose wages for the next year are set in advance-- in Shea s empirical analysis, the se are unionized teachers whose contract is negotiated one year ahead. In the standard the ory, if next year s wage is surprisingly good, then the teachers should spend more now, and if next year s wage is disappointingly low, the teachers should cut back on their spending now. In fact, the teachers in Shea s study did spend more when their future wages were expected to rise, but they did not cut back when their future wages were cut.

Bowman, Minehart and Rabin (BMR, 1997) can explain this pattern with a stylized twoperiod consumption-savings model in which workers have reference-dependent utility, $u(c(t)-r(t))$. The utility they get from consumption in each period exhibits loss-aversion (the marginal utility of 
consuming just enough to reach the reference point is always strictly larger than the marginal utility from exceeding it) and a reflection effect (if people are consuming below their reference point, the marginal ut ility of consumption rises as they get closer to it). Workers begin with some reference point $r(t)$, and save and consume in the first period. Their reference point in the second period is an average of their initial reference point and their first-period consumption, so $r(2)=r(1)+(1-) c(1)$. The pleasure workers get from consuming in the second period depends on how much they consumed in the first period, through the effect of previous consumption on the current reference point. If they consumed a lot at first, they will be disappointed if their standard of living is cut.

BMR show formally how this simple model can explain the behavior of the teachers in Shea s study. Suppose teachers are consuming at their reference point, and they get bad news about future wages (in the sense that the distribution of possible wages next year shifts downward). BMR show that the teachers may not cut their current consumption at all. Consumption is sticky downward for two reasons: First, because they are loss-averse, cutting current consumption means they will consume below their reference point this year, which feels awful. Second, because of reflection effects, they are willing to gamble that next year s wages might not turn out so bad-- they would rather take a gamble in which they either consume far below their reference point or consume right at it, than accept consumption which is modestly below the reference point. The se two forces make the teachers reluctant to cut their current consumption after receiving bad news about future income prospects, explaining Shea s finding.

\section{Status quo bias, endowment effects, and buying-selling price gaps}

Samuelson and Zeckhauser (1988) coined the term status quo bias to refer to an exaggerated preference for the stat us quo, and showed such a bias in a series of experiments. They also reported several observations in field data which are consistent with status quo bias.

When Harvard University adde d new health-care plan options, older faculty members who were hired previously, when the new options were not available were, of course, allowed to switch to the new options. If one assumes that the new and old faculty members have essentially the same preferences for health care plans, then the distribution of plans elected by new and old faculty should be the same. However, Samuelson and Zeckhauser found that older faculty members tended to stick to their previous plans; compared to the newer faculty members, fewer of the old faculty elected new options.

In cases where there is no status quo, people may have an exaggerated preference for whichever option is the default choice. Johnson, Hershey, Meszaros, and Kunreuther (1993) observed this phenomenon in decisions involving insurance purchases. At the time of their study, Pennsylvania and New Jersey legislators were considering various kinds of tort reform, allowing firms to offer cheaper automobile insurance which limited the rights of the insured person to sue for damages from accidents. Both states adopted very similar forms of limited insurance, but they chose different default options, creating a natural experiment. All insurance companies mailed forms to their customers, asking the customers whether they wanted the cheaper limited-rights 
insurance or the unlimited-rights insurance. One state made the limited-rights insurance the default-- the insured person would get that if they did not respond-- and the other made unlimited-rights the default. In fact, the percentage of people electing the limited-rights insurance was higher in the state where that was the default. An experiment replicated the effect.

A closely related body of research on endowment effects established that buying and selling prices for a good are often quite different. The paradigmatic experimental demonstration of this is the mugs experiments of Kahneman, Knetsch and Thaler (1990). In their experiments, some subjects are endowed (randomly) with coffee mugs and others are not. Those who are given the mugs demand a price about 2-3 times as large as the price that those without mugs are willing to pay, even though in economic theory these prices should be extremely close together. In fact, the mugs experiments were inspired by field observations of large gaps in hypothetical buying and selling prices in contingent valuations. Contingent valuations are measurements of the economic value of goods which are not normally traded-- like clean air, environmental damage, and so forth. These money valuations are used for doing benefit-cost analysis and establishing economic damages in lawsuits. There is a huge literature establishing that selling prices are generally much larger than buying prices, although there is a heated debate among psychologists and economists about what the price gap means, and how to measure true valuations in the face of such a gap.

All three phenomena-- status quo biases, default preference, and endowment effects-- are consistent with aversion to losses relative to a reference point. Making one option the status quo or default, or endowing a person with a good (even hypothetically), seems to establish a reference point people move aw ay from only reluctantly, or if they are paid a large sum.

\section{Racetrack betting: The favorite-longshot bias}

In parimutuel betting on horse races, there is a pronounced bias toward betting on longshots, horses with a relatively small chance of winning. That is, if one groups longshots with the same percentage of money bet on them into a class, the fraction of time horses in that class win is far smaller than the percentage of money bet on them. Horses with $2 \%$ of the total money bet on them, for example, win only about $1 \%$ of the time (see Thaler and Ziemba, 1988; Hausch and Ziemba, 1995).

The fact that longshots are overbet implies favorites are underbet. Indeed, some horses are so heavily favored that up to $70 \%$ of the win money is wagered on them. For these heavy favorites, the return for a dollar bet is very low if the horse wins. (Since the track keeps about $15 \%$ of the money bet for expenses and profit, bettors who bet on such a heavy favorite share only $85 \%$ of the money with $70 \%$ of the people, a payoff of only about $\$ 2.40$ for a $\$ 2$ bet.) People dislike these bets so much that in fact, if you make tho se bets you can earn a small positive profit (even accounting for the track s 15\% take).

There are many explanations for the favorite-longshot bias, each of which probably contributes to the phenomenon. Horses that have lost many races in a row tend to be longshots, so a gambler s fallacy belief that such horses are due for a win may contribute to overbetting on them. Prospect-theoretic overweighting oflow probabilities of winning will also lead to overbetting of longshots. 
Within standard expected utility theory, the favorite-longshot bias can only be explained by assuming that people have convex utility functions for money outcomes. The most careful study comparing expected utility and prospect theory was done by Jullien and Salanié (1997). Their study used a huge sample of all the flat races run in England for ten years $(34,443$ races). They assume that bettors value bets on horses using either expect ed utility theory, rank-dependent utility theory, or cumulative prospect theory (see Kahneman and Tversky, 1992). If the marginal bettor is indifferent among bets on all the horses at the odds established when the race is run, then indifference conditions can be used to infer the parameters of that bettor s utility and probability weighting functions.

Jullien and Salanié find that cumulative prospect theory fits much better than rankdependent theory and expected utility theory. They estimate that the utility function for small money amounts is convex. Their est imate of the probability weighting function (p) for probabilities of gain is almost linear, but the weighting function for loss probabilities severely overweights low probabilities of loss (e.g., $(.1)=.45$ and $(.3)=.65)$. These estimates imply a surprising new explanation for the favorite-longshot bias: Bettors like longshots because they have convex utility and weight the ir high chances of losing and small chances of winning roughly linearly. But they hate favorites because they like to gamble $(\mathrm{u}(\mathrm{x})$ is convex $)$, but are disproportionately afraid of the small chance of losing when they bet on a heavy favorite. (In my personal experience as a betting researcher I ve found that losing on a heavy favorite is particularly disappointing, an emotional effect the Jullien-Salanié estimates seem to capture.)

\section{Racetrack betting: The end-of-the-day effect}

McGlothlin (1956) and Ali (1977) established another racetrack anomaly which points to the central role of reference points. They found that bettors tend to shift their bets toward longshots, and away from favorites, later in the racing day. Because the track takes a hefty bite out of each dollar, most bettors are behind by the last race of the day. These bettors really prefer longshots because a small longshot bet can generate a large enough profit to cover their earlier losses, enabling them to break even. The movement toward longshots, and away from favorites, is so pronounced that some studies show that betting on the favorite to show (to finish first, second, or third) in the last race is a profitable bet, even despite the track s take.

The end-of-the-day effect is consistent with using zero daily pro fit as a reference point and gambling in the do main of loss es to break even. Expec ted utility theory cannot grac efully explain the shift in risk preferences across the day if bettors integrate their wealth because the last race on Saturday is not fundamentally different than the first race on the bettor s next outing. Cumulative prospect theory can explain the shift by assuming people open a mental account at the beginning of the day, close it at the end, and hate closing an account in the red.

\section{State lotteries}

Lotto is a special kind of lottery game in which players choose six different numbers from a set of 40-50 numbers. They win a large jackpot if their six choice match six numbers which are randomly drawn in public. If no player picks all six numbers correctly, the jackpot is rolled 
over and added to the next week s jackpot; several weeks of rollovers can build up jackpots up to $\$ 50$ million or more. The large jackpots have made Lotto very popular. ${ }^{3}$ Lotto was introduced in several American states in 1980, and account ed for about half of all state lottery ticket sales by 1989.

Cook and Clotfelter (1993) suggest that the popularity of Lotto is due to the fact that players are more sensitive to the large jackpot than to the correspondingly low probability of winning. They write (p. 634):

If players tend to judge the likelihood of winning based on the frequency with which someone wins, then a larger state can offer a game at longer odds but with the same perceived probability of winning as a smaller state. The larger population base in effect conceals the smaller probability of winning the jackpot, while the larger jackpot is highly visible. This interp retation is congruent with prospect theory.

Their regressions show that across states, ticket sales are strongly correlated with the size of a state s population (which is correlated with jackpot size). Within a state, ticket sales each week are strongly correlated with the size of the rollover. In expected utility, this can only be explained by utility functions for money which are convex. Pro spect theory easily explains the demand for high jackpots, as Cook and Clotfelter suggest, by overweighting of, and insensitivity toward, very low probabilities.

\section{Telephone wire repair insurance}

Ciccheti and Dubin (1994) conducted an interesting study of whether people purchase insurance against damage to their telephone wiring. The phone companies they studied either require customers to pay for the cost of wiring repair, about $\$ 60$, or buy insurance for $\$ .45$ per month. Given phone company estimates of the frequency of wire damage, the expected cost of wire damage is only $\$ .26$.

Ciccheti and Dubin looked across geographical areas with different probabilities of wire damage rates, to see whether variation in the tendency to buy insurance was related to different probabilities. They did find a relation, and exploited this to estimate parameters of an expected utility model. They found some evidence that people were weighting damage probabilities nonlinearly, and also some evidence of status quo bias. (People who had previously been uninsured, when a new insurance option was introduced, were less likely to buy it than new customers were.)

More importantly, Ciccheti and Dubin never asked whether it is reasonable to purchase insurance against such a tiny risk. In standard expected utility, a person who is averse to very

${ }^{3}$ A similar bet, the pick six , was introduced at horse racing tracks in the $1980 \mathrm{~s}$. In the pick six, bettors must choose the winners of six races. This is extremely hard to do so a large rollover occurs if no body has picked all six winners several days in a row, just like Lotto. Pick six betting now accounts for a large fraction of overall betting. 
modest risks at all levels of wealth should be more risk-averse to large risks. Rabin (1998b) was the first to demonstrate how dramatic the implications of local risk-aversion are for global riskaversion. He showed formally that a mildly risk-averse expected-utility maximizer who would turn down a coin flip (at all wealth levels) in which she is equally likely to win $\$ 101$ or lose $\$ 100$ should not accept a coin flip in which she could lose $\$ 10,000$, regardless of how much she could win. In expected utility terms, turning down the small-stakes flip implies a lit tle bit of curvature in a \$201 range of a concave utility function. Turning it down for all wealth levels implies the utility function is slightly curved at all wealth levels, which implies a dramatic degree of global curvature.

Rabin s proof implies a rejection of the joint hypotheses that consumers why buy wirerepair insurance are integrating their wealth and valuing the insurance according to expected utility (and know the correct probabilities of damage). A more plausible explanation come immediately from prospect theory-- consumers are overweighting the probability of damage. (Loss-aversion and reflection cannot explain their purchases because if they are loss-averse they should dislike spending the $\$ .45$ per month, and reflection implies they will never insure unless they overestimate the probability of loss.) Once again, narrow bracketing is also required-consumers must be foc using only on wire-repair risk, since otherwise the tiny probability of a modest loss would be absorbed into a portfolio of life s ups and downs and weighted more rea sonably.

\section{Conclusion}

Economists value (i) mathematical formalism and econo metric parsimony, and (ii) the ability of theory to explain naturally-occurring data. (I share these tastes.) This paper showed that prospect theory is valuable in both ways because it can explain 10 patterns observed in a wide variety of economic domains with a small number of modelling features. Different features of prospect theory help explain different patterns. Loss-aversion can explain the extra return on stocks compared to bonds (the equity premium), the tendency of cab drivers to work longer hours on low-wage days, asymmetries in consumer reactions to price increases and decreases, the insensitivity of consumption to bad new about income, and status quo and endowment effects.

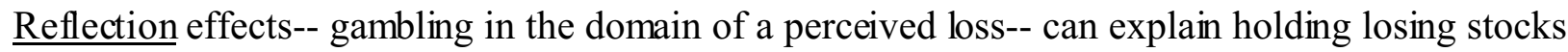
longer than winners (dispo sition effects), insens itivity of consumption to bad income news, and the shift toward longshot betting at the end of a racetrack day. Nonlinear weighting of probabilities can explain the favorite-longshot bias in horse race betting, the popularity of Lotto lotteries with large jackpots, and the purchase of telephone wire repair insurance. In addition, the disposition effect and downward-sloping labor supply of cab drivers were not simply observed, but were also predicted in advance, based on prospect theory.

In virtually all these examples it is also necessary to assume people are isolating or narrowly bracketing the relevant decisions. Bracketing narrowly focuses attention most dramatically on the possibility of a loss or extreme outcome, or a low probability. With broader bracketing, outcomes are mingled with other gains and losses, diluting the psychological influence of any single outcome and making these phenomena hard to explain as a result of prospect theory valuation. 
I have two final comments. First, I have chosen examples in which there are several studies, or at least one very conclusive one, showing regularities in field data which cannot be easily reconciled with expected utility theory. These regularities can sometimes be explained by adding extra assumptions. The problem is that these extras are truly ad hoc because each regularity requires a special extra assumption. Worse, an extra assumption which helps explain one regularity may contradict another. For example, assuming people are risk-preferring (i.e., have convex utility for money) can explain the popularity of longshot horses and Lotto, but that assumption predicts stocks should return less than bonds, which is wildly false. You can explain why cab drivers drive long hours on bad days by assuming they cannot borrow (they are liquidity-constrained ), but liquidity-constraint implies teachers who get good income news should not be able to spend more, while those who get bad news can cut back, which is exactly the opposite of what they do.

Second, prospect theory is a suitable replacement for expected utility because it can anomalies like those listed above, and can also explain the most basic phenomena expected utility is used to explain. A prominent example is pricing of financial assets, discussed above in sections 1-2. Another prominent example, which appears in every economics textbook, is the voluntary purchase of insurance by people. The expected utility explanation for why people buy actuarially unfair insurance is that they have concave utility, so they hate losing large amounts of money disproportionally, compared to spending small amounts on insurance premia.

In fact, many people do not purchase insurance voluntarily (e.g., most states require automobile insurance by law). The failure to purchase is inconsistent with the expected utility explanation, and more easy to reconcile with prospect the ory (because the disutility of loss is assumed to be convex). When people do buy insurance, people are probably avoiding lowprobability disasters which they overweight (the prospect theory explanation), rather than avoiding a steep drop in a concave utility function (the expected utility theory explanation).

A crucial kind of evidence which distinguishes the two explanations comes from experiments on probabilistic insurance -- insurance which does not pay a claim, if an accident occurs, with some probability $\mathrm{r}$. According to expected utility theory, if $r$ is small people should pay approximately (1-r) times as much for probabilistic insurance as they pay for full insurance (Wakker, Thaler, and Tversky, 1997). But experimental responses show that people hate probabilistic insurance; they pay a multiple much less than 1-r for it (for example, they pay $80 \%$ as much when $\mathrm{r}=.01$ ). Prospect theory can explain their hatred easily-- probabilistic insurance does not reduce the probability of loss all the way toward zero, and the low probability $r$ is still overweighted. Prospect theory can therefore explain why people buy full insurance, and why they do not buy probabilistic insurance. Expected utility cannot do both.

Since prospect theory can explain some of the basic phenomena expected utility was most fruitfully applied to, like asset pricing and insurance purchase, and can also explain field anomalies like the 10 listed in Table 1 (two of which were predicted), there is no good scientific reason why it should not replace expected utility in current research, and be given prominent space in economics textbooks. 


\section{References}

Ali, Muhktar. Probability and utility estimates for racetrack bettors. Journal of Political Economy, 85, 1977, 803-815.

Benartzi, Shlomo and Richard Thaler, Myopic Loss Aversion and the Equity Premium Puzzle, Quarterly Journal of Economics 110, 1995, 73-92.

Bowman, David, Debby Minehart, and Matthew Rabin. Loss Aversion in a Savings Model, University of California, Berkeley working paper, 1997.

Camerer, Colin F. Individual decision making . In A. E. Roth and J. Kagel (Eds.), Handbook of Experimental Economics. Princeton: Princeton University Press, 1995.

Camerer, Colin F.; Babcock, Linda; Loewenstein, George; and Richard Thaler. Labor Supply of New York City Cab drivers: One day at a time, this volume.

Ciccheti, Charles and Jeff Dubin. A microeconometric analysis of risk-aversion and the decision to self-insure. Journal of Political Economy, (1994) 102, 169-186.

Cook, Philip J and Clotfelter, Charles T. The peculiar scale economies of Lotto. American Economic Review 83 (June 1993): 634-643.

Hardie, Bruce G. S., Eric J. Johnson and Peter S. Fader, Modeling Loss Aversion and Reference Dependence Effects on Brand Choice, Marketing Science, (1993).

Hausch, Donald B. And William T. Ziemba. Efficiency in sports and lottery betting markets. In Handbook of Finance, edited by R. A. Jarrow, V. Maksimovic, and W. T. Ziemba. Amsterdam: North-Holland, 1995.

Johnson, Eric; Hershey, Jack; Meszaros, Jacqueline; and Howard Kunreuther. Framing, probability distortions, and insurance decisions. Journal of Risk and Uncertainty. 1993, 7, 35-51.

Jullien, Bruno and Salanié, Bernard. Estimating preferences under risk: The case of racetrack bettors. IDEI and GREMAQ Toulouse University working paper, 1997.

Kahneman, Daniel and Amos Tversky. Advances in Prospect Theory: Cumulative Representation of Uncertainty Journal of Risk and Uncertainty 5 (October 1992) 297-324.

Kahneman, D., J. L. Knetsch and R. Thaler. 1990. Experimental tests of the endowment effect and the Coase Theorem. Journal of Political Economy 98:1325-1348. 
McGlothlin, W. H. 1956. Stability of choices among uncertain alternatives. American Journal of Psychology 69: 604-615.

Mehra, Rajneesh and Edward Prescott. The equity premium puzzle. Journal of Monetary Economics, 1985.

Odean, Terrance. Are investors reluctant to realize their losses? forthcoming in Journal of Finance, 1998.

Putler, Chris. Marketing Science, 1992.

Rabin, Matthew. Psychology and economics. Journal of Economic Literature, 36, 1998a, 11-46.

Rabin, Matthew. Risk-aversion: A calibration theorem, Unpublished University of California, Berkeley Department of Economics working paper. 1998b.

Read, Daniel; Loewenstein, George; and Matthew Rabin. Choice bracketing, Carnegie-Mellon Dept Social and Decision Sciences working paper, 1998.

Samuelson, William. and Richard Zeckhauser. 1988. Status quo bias in decision making. Journal of Risk and Uncertainty 1:7-59.

Shea, John, Union Contracts and the Life-Cycle/Permanent-Income Hypothesis, American Economic Review, 85, 1995, 186-200.

Shefrin, Hersh and Statman, Meier. The disposition to sell winners too early and ride losers too long. Journal of Finance, 40, 1985, 777-790.

Siegel, Jeremy and Richard Thaler. The equity premium puzzle. Journal of Economic Perspectives, 1997.

Thaler, Richard H. Mental accounting matters. This volume.

Thaler, Richard and Ziemba, William T. Parimutuel betting markets: Racetracks and lotteries. Journal of Economic Perspectives, 2, 1988, 161-174.

Wakker, Peter P.; Thaler, Richard H. ; and Amos Tversky. Probabilistic insurance. Journal of Risk and Uncertainty, 1997, 15, 5-26.

Weber, Martin and Colin Camerer. The disposition effect in securities trading: An experimental analysis. Journal of Economic Behavior and Organization, 33, 1998, 167-184. 


\begin{tabular}{|c|c|c|c|c|c|c|}
\hline DOMAIN & PHENOMENON & DESCRIPTION & $\begin{array}{l}\text { TYPE OF } \\
\text { DATA }\end{array}$ & $\begin{array}{l}\text { ISOLATED } \\
\text { DECISION }\end{array}$ & $\begin{array}{l}\text { INGRED- } \\
\text { IENTS }\end{array}$ & REFRERENCES \\
\hline $\begin{array}{l}\text { Stock } \\
\text { market }\end{array}$ & Equity pre mium & $\begin{array}{l}\text { Stock returns are too } \\
\text { high, relative to bond } \\
\text { returns }\end{array}$ & $\begin{array}{l}\text { NYSE stock, } \\
\text { bond returns }\end{array}$ & $\begin{array}{l}\text { Single yearly } \\
\text { return (not } \\
\text { long-run) }\end{array}$ & $\begin{array}{l}\text { Loss- } \\
\text { aversion }\end{array}$ & $\begin{array}{l}\text { Benartzi and } \\
\text { Thaler (1995) }\end{array}$ \\
\hline $\begin{array}{l}\text { Stock } \\
\text { market }\end{array}$ & Disposition effect & $\begin{array}{l}\text { Hold losing stock too } \\
\text { long, sell winners too } \\
\text { early }\end{array}$ & $\begin{array}{l}\text { Individual } \\
\text { invest or } \\
\text { trades }\end{array}$ & $\begin{array}{l}\text { Single stock } \\
\text { (not portfolio) }\end{array}$ & $\begin{array}{l}\text { Reflection } \\
\text { effect }\end{array}$ & Odean (in press) \\
\hline $\begin{array}{l}\text { Labor } \\
\text { economics }\end{array}$ & $\begin{array}{l}\text { Downward- } \\
\text { sloping labor } \\
\text { supply }\end{array}$ & $\begin{array}{l}\text { NYC cabdrivers quit } \\
\text { around daily income } \\
\text { target }\end{array}$ & $\begin{array}{l}\text { Cabdriver } \\
\text { hours, } \\
\text { earnings }\end{array}$ & $\begin{array}{l}\text { Single day } \\
\text { (not week or } \\
\text { month) }\end{array}$ & $\begin{array}{l}\text { Loss- } \\
\text { aversion }\end{array}$ & $\begin{array}{l}\text { Camerer et al } \\
\text { (1997) }\end{array}$ \\
\hline $\begin{array}{l}\text { Consumer } \\
\text { goods }\end{array}$ & $\begin{array}{l}\text { Asymmetric price } \\
\text { elasticities }\end{array}$ & $\begin{array}{l}\text { Purchases more } \\
\text { sensitive to price } \\
\text { increases than to cuts }\end{array}$ & $\begin{array}{l}\text { Product } \\
\text { purchases } \\
\text { (scanner data) }\end{array}$ & $\begin{array}{l}\text { Single } \\
\text { product (not } \\
\text { shopping cart) }\end{array}$ & $\begin{array}{l}\text { Loss- } \\
\text { aversion }\end{array}$ & $\begin{array}{l}\text { Hardie, Johnson, } \\
\text { Fader (1993) }\end{array}$ \\
\hline $\begin{array}{l}\text { Macro- } \\
\text { economics }\end{array}$ & $\begin{array}{l}\text { Insensitivity to } \\
\text { bad income news }\end{array}$ & $\begin{array}{l}\text { Consumers do not cut } \\
\text { consumption after bad } \\
\text { income news }\end{array}$ & $\begin{array}{l}\text { Teachers } \\
\text { earning, } \\
\text { savings }\end{array}$ & Single year & $\begin{array}{l}\text { Loss- } \\
\text { aversion, } \\
\text { reflection } \\
\text { effect }\end{array}$ & $\begin{array}{l}\text { Shea (1994); } \\
\text { Bowman, } \\
\text { Minehart and } \\
\text { Rabin (1996) }\end{array}$ \\
\hline $\begin{array}{l}\text { Consumer } \\
\text { choice }\end{array}$ & $\begin{array}{l}\text { Status quo bias, } \\
\text { Default bias }\end{array}$ & $\begin{array}{l}\text { Consumers do not } \\
\text { switch health plans, } \\
\text { choose default } \\
\text { insurance }\end{array}$ & $\begin{array}{l}\text { Health plan, } \\
\text { insurance } \\
\text { choices }\end{array}$ & Single choice & $\begin{array}{l}\text { Loss- } \\
\text { aversion }\end{array}$ & $\begin{array}{l}\text { Samuelson and } \\
\text { Zeckhauser } \\
(1988), \text { Johnson } \\
\text { et al (1992) }\end{array}$ \\
\hline $\begin{array}{l}\text { Horserace } \\
\text { betting }\end{array}$ & $\begin{array}{l}\text { Favorit e-long shot } \\
\text { bias }\end{array}$ & $\begin{array}{l}\text { Favorites are underbet, } \\
\text { longshots overbet }\end{array}$ & Track odds & $\begin{array}{l}\text { Single race } \\
\text { (not day) }\end{array}$ & $\begin{array}{l}\text { Overweight } \\
\text { low p(loss) }\end{array}$ & $\begin{array}{l}\text { Jullien and } \\
\text { Salanié (1997) }\end{array}$ \\
\hline $\begin{array}{l}\text { Horserace } \\
\text { betting }\end{array}$ & $\begin{array}{l}\text { End-of-the-day } \\
\text { effect }\end{array}$ & $\begin{array}{l}\text { Shift to longshots at } \\
\text { the end of the day }\end{array}$ & Track odds & Single day & $\begin{array}{l}\text { Reflection } \\
\text { effect }\end{array}$ & $\begin{array}{l}\text { McGlothlin } \\
(1956)\end{array}$ \\
\hline Insurance & $\begin{array}{l}\text { Buying phone } \\
\text { wire insurance }\end{array}$ & $\begin{array}{l}\text { Consumers buy } \\
\text { overpriced in surance }\end{array}$ & $\begin{array}{l}\text { Phone wire } \\
\text { insurance } \\
\text { purchases }\end{array}$ & $\begin{array}{l}\text { Single wire } \\
\text { risk (not } \\
\text { portfol io) }\end{array}$ & $\begin{array}{l}\text { Overweight } \\
\text { low p(loss) }\end{array}$ & $\begin{array}{l}\text { Cicchetti and } \\
\text { Dubin (1994) }\end{array}$ \\
\hline $\begin{array}{l}\text { Lottery } \\
\text { betting }\end{array}$ & $\begin{array}{l}\text { Demand for } \\
\text { Lotto }\end{array}$ & $\begin{array}{l}\text { More tickets sold as } \\
\text { top prize rises }\end{array}$ & $\begin{array}{l}\text { Sta te lottery } \\
\text { sales }\end{array}$ & Single lottery & $\begin{array}{l}\text { Overweight } \\
\text { low } p \text { (win) }\end{array}$ & $\begin{array}{l}\text { Cook and } \\
\text { Clotfelter (1993) }\end{array}$ \\
\hline
\end{tabular}

